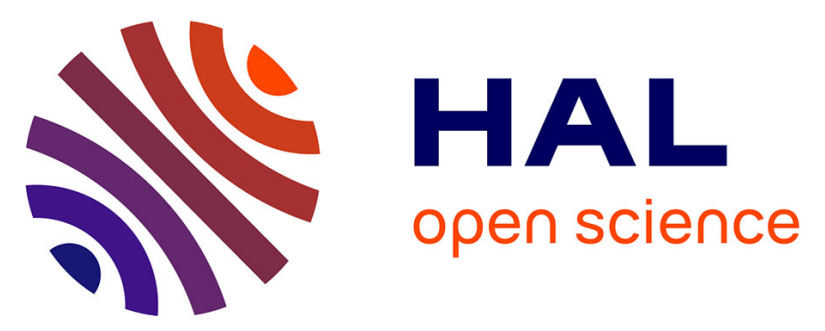

\title{
A [3]Ferrocenophane polyphenol showing a remarkable antiproliferative activity on breast and prostate cancer cell lines
}

\author{
Damian Plazuk, Anne Vessières, Elisabeth A. Hillard, Olivier Buriez, Eric \\ Labbé, Pascal Pigeon, Marie-Aude Plamont, Christian Amatore, Janusz \\ Zakrzewski, Gérard Jaouen
}

\section{To cite this version:}

Damian Plazuk, Anne Vessières, Elisabeth A. Hillard, Olivier Buriez, Eric Labbé, et al.. A [3]Ferrocenophane polyphenol showing a remarkable antiproliferative activity on breast and prostate cancer cell lines. Journal of Medicinal Chemistry, 2009, 52, pp.4964-4967. 10.1021/jm900297x . hal00448988

\section{HAL Id: hal-00448988 \\ https://hal.science/hal-00448988}

Submitted on 20 Jun 2018

HAL is a multi-disciplinary open access archive for the deposit and dissemination of scientific research documents, whether they are published or not. The documents may come from teaching and research institutions in France or abroad, or from public or private research centers.
L'archive ouverte pluridisciplinaire HAL, est destinée au dépôt et à la diffusion de documents scientifiques de niveau recherche, publiés ou non, émanant des établissements d'enseignement et de recherche français ou étrangers, des laboratoires publics ou privés. 


\section{A [3]Ferrocenophane Polyphenol Showing a Remarkable Antiproliferative Activity on Breast and Prostate Cancer Cell Lines}

Damian Plażuk, ${ }^{1,2}$ Anne Vessières, ${ }^{1}$ Elizabeth A. Hillard, ${ }^{1}$ Olivier Buriez, ${ }^{3}$ Eric Labbé, ${ }^{3}$ Pascal Pigeon, ${ }^{1}$ Marie-Aude Plamont, ${ }^{1}$ Christian Amatore, ${ }^{3}$ Janusz Zakrzewski, ${ }^{2}$ and Gérard Jaouen *,1

${ }^{1}$ Ecole Nationale Supérieure de Chimie de Paris, Laboratoire Charles Friedel, UMR CNRS 7223, 11 rue Pierre et Marie Curie, 75231 Paris Cedex 05, France, ${ }^{2}$ Department of Organic Chemistry, University of Łódż, Narutowicza 68, 90-136 Łódż, Poland, and ${ }^{3}$ Ecole Normale Supérieure, Département de Chimie, UMR CNRS-ENS-UPMC 8640 "Pasteur”, 24 rue Lhomond, F-75231 Paris Cedex 05, France

*To whom correspondence should be addressed. Phone: (+33) 1432695 55. Fax: (+33) 1432600 61. E-mail: gerard-jaouen@enscp.fr.

$a$ ER, estrogen receptor; RBA, relative binding affinity; CV, cyclic voltammogram; $\mathrm{QM}$, quinone methide; $\mathrm{CD}$, partially methylated $\beta$-cyclodextrin; Fc, ferrocene.

We have previously shown that modification of polyphenols with a ferrocenyl group can dramatically enhance their cytotoxicity. We now present two new [3]ferrocenophane compounds, one of which has an antiproliferative effect seven times stronger than the corresponding noncyclic species, with $\mathrm{IC}_{50}$ values of 90 and $94 \mathrm{nM}$ on hormoneindependent MDA-MB-231 breast and PC-3 prostate cancer cell lines, respectively. Solubility studies in water using methylated $\beta$-cyclodextrin and electron transfer studies are also presented. 


\section{Introduction}

Bioorganometallic chemistry is driving an increasing amount of growth in drug design. ${ }^{1-3}$ As part of an ongoing study of biologically active organometallic compounds, we have described a reasoned approach to preparing a new family of metallocene complexes with strong antitumor potential. This approach involves the substantial modification of the biological properties of polyphenols by the covalent addition of a ferrocenyl group to the organic skeleton. ${ }^{4-11}$ Compound $\mathbf{1}$ (Chart 1) is estrogenic on MCF7 hormone-dependent breast cancer cells, promoting cell proliferation, while 2, bearing a ferrocenyl entity, produces a powerful antiproliferative effect on both MCF-7 cells and MDA-MB-231 hormone-independent breast cancer cells. ${ }^{4}$ Likewise, while the natural polyphenol resveratrol 3 has an $\mathrm{IC}_{50}$ value as high as $20 \mu \mathrm{M}$ on MDA-MB-231 cells, ${ }^{12}$ the $\mathrm{IC}_{50}$ value for 2 is on the order of $0.5 \mu \mathrm{M},{ }^{4}$ a 40 -fold improvement. Thus, although organic polyphenols are not efficacious at a therapeutic level, modification with $\mathrm{Fc}^{a}$ vastly improves their antiproliferative properties in vitro.

It should be emphasized that the simple presence of a ferrocenyl group is not sufficient to generate cytotoxic compounds. ${ }^{11}$ For example, a proliferative effect was found on estrogen receptor (ER) positive cells for the molecule created by the attachment of a ferrocenyl group to the $17 \beta$ position of the natural hormone estradiol. ${ }^{13}$ Both the position and the structural pattern in which Fc is inserted are important, and the motif $[\mathrm{Fc}]-[$ conjugated spacer]-[p-phenol] seems to be crucial for strong cytotoxic effects; a change in the position of either the $\mathrm{OH}$ or ferrocenyl group resulted in a weakened cytotoxic effect. ${ }^{5-9}$

Our aim is now to seek related molecules that may have even higher efficacy than 2. We envisaged solutions based on new structures while preserving the key ferrocenylphenol motif, and it seemed to us that constrained ring structures were particularly appropriate. Rigid molecules can bind more strongly to a receptor than their flexible analogues if they have the proper geometry for entering the active site, while a flexible molecule must adopt such a geometry, causing entropy loss and weaker binding. Accordingly, molecules 4 and 5, based on the [3]ferrocenophane motif, were prepared and studied (Chart 2). Molecule 4 possesses a direct linkage between the cyclopentadienyl ring 
and the double bond, while the other cyclopentadienyl is attached to the double bond by a two-carbon bridge. In $\mathbf{5}$, the ferrocenyl is symmetrically linked to the double bond by a single-carbon bridge.

\section{Results}

Compound 4 was obtained in $28 \%$ yield via a McMurry cross-coupling reaction with the ferrocenophanone 6 and 4,4'-dihydroxybenzophenone (Scheme 1). Compound 6 could be obtained via the reaction of Fc with acryloyl chloride in the presence of aluminum chloride, ${ }^{14,15}$ or alternatively, via the acylation of $\mathrm{Fc}$ with ethyl mono-malonate, ${ }^{16}$ followed by Clemmensen reduction of the resulting ketoester and hydrolysis and cyclization of the ferrocenylpropionic acid formed. The synthesis of 5 required 1,1'-(2ketotrimethylene)ferrocene, which has been previously reported. ${ }^{17} \mathrm{~A}$ McMurry crosscoupling reaction of this compound with 4,4'-dihydroxybenzophenone gave $\mathbf{5}$ as a yellow powder in $22 \%$ yield.

The relative binding affinity (RBA) to ER, lipophilicity, and proliferative/antiproliferative effects against the MCF-7 ER+ breast, the MDA-MB-231 ER- breast, and the PC-3 AR-prostate cancer cell lines are reported in Table 1, along with the values obtained for the noncyclic compound 2 for comparison. Molecules $\mathbf{4}$ and 5 recognize $\mathrm{ER} \alpha$ and $\mathrm{ER} \beta$, present in varying degrees in MCF-7 cells, with overall values on the same order of magnitude as that of $\mathbf{2}$. However, $\mathbf{4}$ and $\mathbf{5}$ exhibit different behavior on the growth of MCF-7 cells. After five days of culture, 4 is estrogenic at low concentration (10 nM; 124\% vs control) and becomes cytotoxic at higher concentration (100 nM; 69\%). At $10 \mathrm{nM}, 5$ is estrogenic after 4 days of culture (118\%) but, unusually, becomes cytotoxic after 5 days of culture (80\%). $\mathrm{IC}_{50}$ values of $4 \mu \mathrm{M}$ for 4 and of $1 \mu \mathrm{M}$ for 5 can be estimated for MCF-7 cells after five days of incubation. It is clear that there is a competition on this cell line between the estrogenic (positive) and cytotoxic (negative) effects, and it seems from these results that $\mathbf{4}$ is more estrogenic than $\mathbf{5}$. Surprisingly, this could not be predicted from the RBA values, which are quite similar. Overall, the values for MCF-7 cells are on the same order of magnitude as that of the noncyclic diphenol 2.

Compound 4 shows an exceptional antiproliferative effect on the hormone-independent 
MDA-MB-231 and PC-3 cells, with an $\mathrm{IC}_{50}$ value of $0.09 \mu \mathrm{M}$, an order of magnitude more cytotoxic than 5, which lacks conjugation between the phenol and the ferrocenyl groups. The cytotoxic effect of compound 2, lacking the ferrocenophane structure but possessing a conjugated system, falls intermediate between $\mathbf{4}$ and $\mathbf{5}$.

Table 1. RBA, $\log P_{\mathrm{O}} / \mathrm{w}$, and the Effect on Cancer Cell Growth of 2, 4, and 5

\begin{tabular}{cccccc}
\hline & \multicolumn{2}{c}{$\mathrm{RBA}(\%)$} & & \multicolumn{2}{c}{$\mathrm{IC}_{50}(\mu \mathrm{M})^{a}$} \\
\cline { 2 - 3 } \cline { 5 - 6 } $\operatorname{ER} \alpha$ & $\mathrm{ER} \beta$ & $\log P_{\mathrm{O} / \mathrm{w}}$ & $\mathrm{MDA}-\mathrm{MB}-231$ & $\mathrm{PC}-3$ \\
\hline $\mathbf{2}$ & $9.6 \pm 0.9$ & $16.3 \pm 1.5$ & 5.0 & $0.64 \pm 0.06$ & $0.7(1 \mathrm{exp})$ \\
$\mathbf{4}$ & $7.2 \pm 0.7$ & $4.84 \pm 0.4$ & 4.6 & $0.09 \pm 0.01$ & $0.094 \pm 0.006$ \\
$\mathbf{5}$ & $7.6 \pm 0.6$ & $15.4 \pm 0.4$ & 4.8 & $0.96 \pm 0.03$ & $1.08 \pm 0.02$ \\
\hline
\end{tabular}

${ }^{a}$ Measured after 5 days of culture (mean of two independent experiments).

Chart 1. Replacement of Ph with Fc on 1 Imparts Cytotoxicity

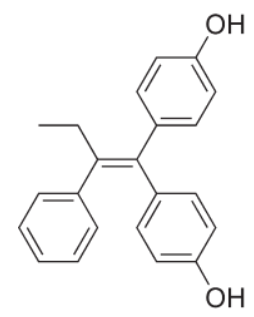

1

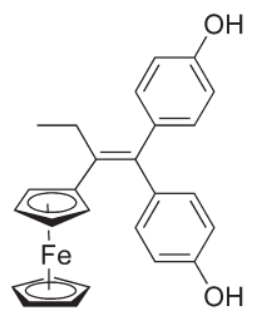

2 Ferrociphenol

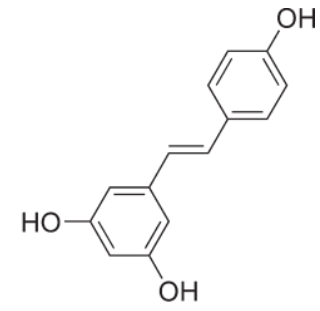

3 Resveratrol

Chart 2. Two New Cytotoxic [3]Ferrocenophanes Studied in This Report
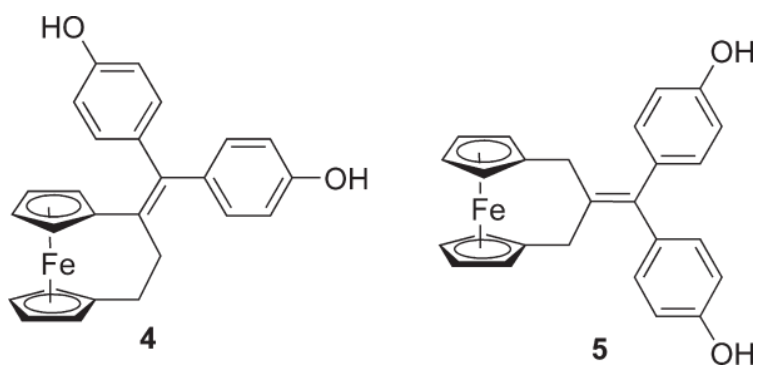


\section{Scheme 1}
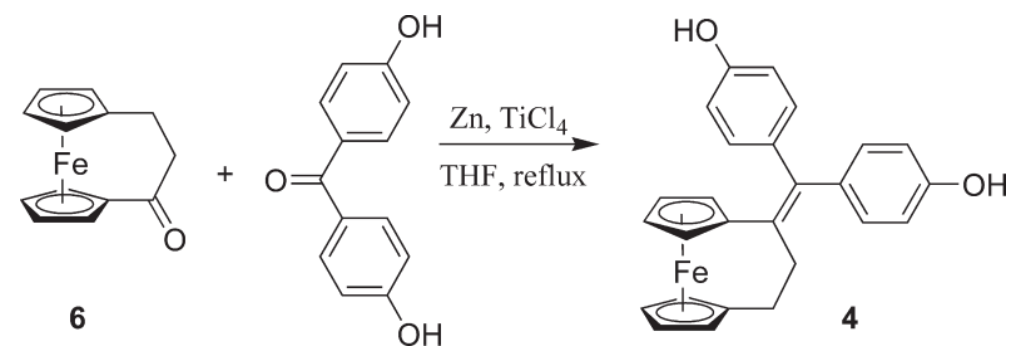

The presence of partially methylated $\beta$-cyclodextrin (CD) does not hinder the in vitro cytotoxic effects of 4 . MDA-MB-231 incubation with the CD-4 complex (obtained by addition to an aqueous solution of 2 equiv of $\mathrm{CD}$ and allowed to dissolve overnight) gave identical results between the free and encapsulated forms $\left(10 \%\right.$ cell survival at $\left.10^{-6} \mathrm{M}\right)$. The complexation of $\mathbf{4}$ with $\mathrm{CD}$ in water was investigated by electrochemistry, as previously reported for $2 .{ }^{18}$ Qualitatively, the time required to dissolve 4 in $\mathrm{H}_{2} \mathrm{O}$ in the presence of $\mathrm{CD}$ was fast compared to that of 2 (20 min vs $1 \mathrm{~h}$ ). The cyclic voltammogram $(\mathrm{CV})$ of the $\mathrm{Fc} / \mathrm{Fc}^{+}$ redox couple obtained with the solution of CD-2 (see Supporting Information) exhibited a plateau shape characteristic of a consecutive chemical-electrochemical mechanism, indicating that the oxidation process was limited by the dissociation step of the complex formed between the $\mathrm{CD}$ and compound $\mathbf{2}$. The peak shape and the faster electron transfer obtained with CD-4 are thus consistent with a weak complexation and a fast decomplexation dynamic.
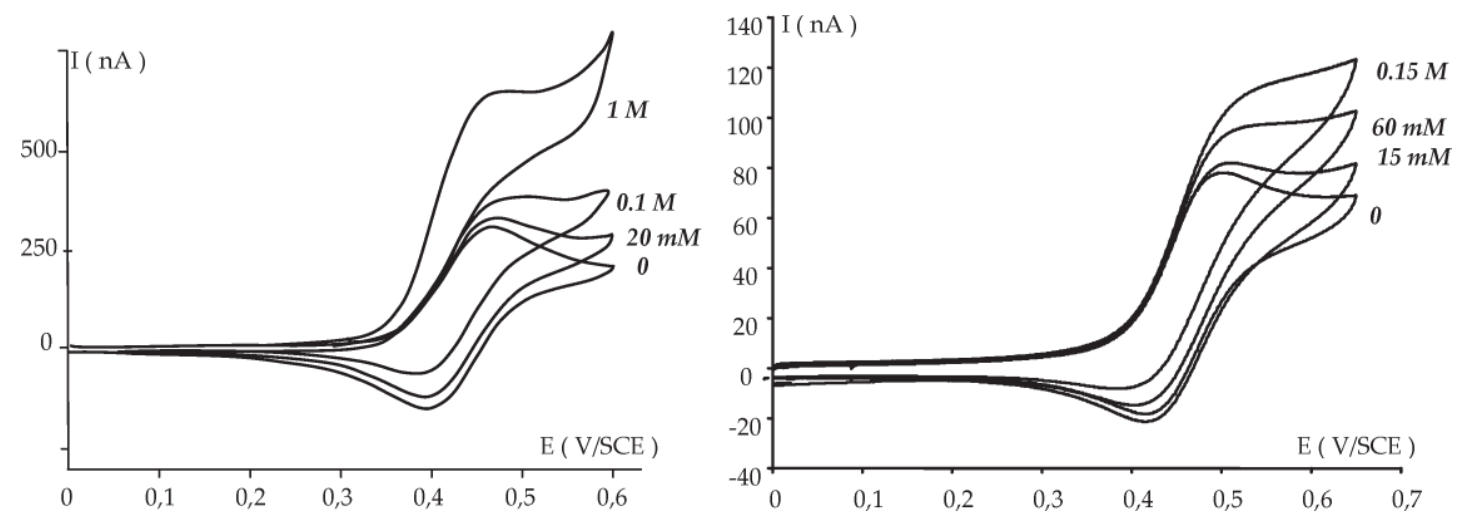

Figure 1. Cyclic voltammograms of $\mathbf{4}(1 \mathrm{mM}$, scan rate $100 \mathrm{mV} / \mathrm{s}$, left $)$ and $\mathbf{5}(0.3$ $\mathrm{mM}$, scan rate $50 \mathrm{mV} / \mathrm{s}$, right) in the presence of varying concentrations of imidazole. 
As observed in Figure 1, in the absence of imidazole, compounds $\mathbf{4}$ and $\mathbf{5}$ exhibit a monoelectronic oxidation process at $0.46 \mathrm{~V}(\mathbf{4})$ and $0.48 \mathrm{~V}(5)$, ascribed to the ferrocenyl oxidation. Upon addition of increasing amounts of base, the intensities of the oxidation waves of both compounds increase, indicating an electron transfer between the phenol and the ferricenium groups prior to the reverse sweep.

\section{Discussion and Conclusions}

Compound 4 represents a major advance in the study of antiproliferative organometallic compounds, with an $\mathrm{IC}_{50}$ value on ER-cells several times lower than our noncyclic lead compound 2. On ER+ cells, 4 displays a combination of estrogenicity and cytotoxicity, which suggests that it should be more efficacious against hormonerefractory tumors. However, to create a compound active against both types of cells, one could eliminate the estrogenic effect by replacing one hydroxyl group with the lateral chain $-\mathrm{O}\left(\mathrm{CH}_{2}\right)_{x} \mathrm{~N}\left(\mathrm{CH}_{3}\right)_{2} \quad(x=3-5)$, as we have previously shown for the hydroxyferrocifen series. ${ }^{19}$

Compound 4 is itself too hydrophobic to envision its intravenous administration, thus possibly limiting its bio-availability for clinical applications. The potency of $\mathbf{4}$ against MDA-MB-231 cells when encapsulated by partially methylated $\beta$-cyclodextrin was maintained. The ability of cyclodextrins to include part of an organometallic complex in their internal hydrophobic cavities has been amply demonstrated, ${ }^{20}$ and both the stoichiometry and the orientation of ferrocenyl depend on the size of the cyclodextrin. The fast complexation/decomplexation dynamic observed suggests that the ferrocenyl group is situated in an equatorial orientation ${ }^{21}$ in such a way that hydrophobic interactions between the phenyl and methoxy groups are minimized.

One of the possible mechanisms that we have identified to explain the cytotoxic effect of ferrocenyl phenols on various cancer cells is based on the in situ transformation to a quinone methide $(\mathrm{QM})$, a process that is mediated by the ferrocenyl group and can be followed by electrochemistry. ${ }^{9}$ Electrochemical experiments suggest that transformation to a QM can be realized for $\mathbf{4}$ and $\mathbf{5}$. In this context, the intramolecular proton coupled electron transfer from the phenol to the ferricenium in $\mathbf{4}$ can be explained by the classical $\pi$ delocalized mechanism. For the unconjugated 5, one must consider either that the 
electron transfer proceeds "through space", or via the formation of an intermediate $\alpha$ methylene radical (such $\alpha$-methylene ferricenium molecules possess acidic protons), ${ }^{22}$ which can delocalize over the $\pi$ system and undergo an additional oxidation step to yield the QM.

It has recently been shown that resveratrol can affect cancer cell growth and induce apoptosis in launching the synthesis of endogenous ceramide, a bioactive sphingolipid. ${ }^{12,25}$ Ceramide is a promising pharmacological target, particularly for cancer therapy. Many drugs that promote the production of ceramide have been proven to be more effective on malignant cells than on healthy tissue, ${ }^{12}$ and this is also the case with compound $2 .^{23-25}$ The idea that compound $\mathbf{4}$, the most effective to date, could possess a high ceramidemediated proapoptotic activity on human breast cancer cells is however just a working hypothesis and will be explored in the future. It remains that $\mathbf{4}$ shows a very strong antiproliferative effect against hormone independent cancer cell lines, and this next generation of cyclic ferrocenyl phenols is currently being expanded for future study.

\section{Experimental Section}

All reactions were performed under inert atmosphere, THF was distilled from $\mathrm{Na} /$ benzophenone, and commercial reagents were used without further purification. Purity of $>95 \%$ was confirmed via elemental analysis for $\mathbf{4}$ and analytical HPLC for $\mathbf{5}$.

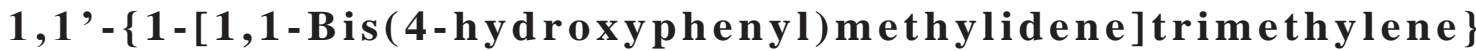

ferrocene (4). To a suspension of $3.07 \mathrm{~g}$ (46.9 mmol) of $\mathrm{Zn}$ dust in $100 \mathrm{~mL}$ of THF and $4.55 \mathrm{~g}(2.64 \mathrm{~mL}, 24 \mathrm{mmol})$ of $\mathrm{TiCl}_{4}$ was added at $-10{ }^{\circ} \mathrm{C}$. The cooling bath was removed, and the mixture was refluxed for $1 \mathrm{~h}$. After cooling to rt, $3.79 \mathrm{~g}(3.87 \mathrm{~mL}, 47.9$ mmol) of anhydrous pyridine was added and the mixture was stirred for $5 \mathrm{~min}$. A solution of $1.92 \mathrm{~g}$ (8 mmol) of [3]ferrocenophan-1-one and $1.71 \mathrm{~g}(8 \mathrm{mmol})$ of 4,4'dihydroxybenzophenone in $30 \mathrm{~mL}$ of THF was added and the mixture was refluxed for 90 min. After cooling to rt, the mixture was hydrolyzed with $100 \mathrm{~mL}$ of $8 \%$ aq $\mathrm{K}_{2} \mathrm{CO}_{3}$. The reaction mixture was extracted with several $100 \mathrm{~mL}$ portions of diethyl ether. The organic phase was washed with water $(2 \times 200 \mathrm{~mL})$ and brine $(200 \mathrm{~mL})$, dried over $\mathrm{MgSO}_{4}$, and evaporated to dryness. Product 4 (2nd yellow fraction) was isolated by flash 
chromatography on silica gel (n-pentane:diethyl ether 2:1). Yield=1.57 g (47\%, purity 9095\%). A second column using $60 \mathrm{~mL}$ of silica gel and $n$-pentane:diethyl ether 4:1 yielded a yellow powder, which was recrystallized from acetone or from a mixture of ethyl acetate $(5 \mathrm{~mL})$ and $n$-pentane $(80 \mathrm{~mL})$ at $4{ }^{\circ} \mathrm{C}$. After $48 \mathrm{~h}$, the organic solution was removed and the yellow crystals washed twice with $n$-pentane. Yield $=0.95 \mathrm{~g}(28 \%) .{ }^{1} \mathrm{H}$ NMR (300.13 MHz, acetone-d $\left.)_{6}\right) 8.31(\mathrm{~s}, 1 \mathrm{H}, \mathrm{OH}), 8.10$ (s, 1H, OH), 7.07 (d, J=8,7 Hz, 2H, Ar), 6.85 (d, J=8,7 Hz, 2H, Ar), 6.84 (d, J=8,7 Hz, 2H, Ar), 6.54 (d, J=8,7 Hz, 2H, Ar), $4.25\left(\mathrm{t}, J=1,7 \mathrm{~Hz}, 2 \mathrm{H}, \mathrm{C}_{5} \mathrm{H}_{4}\right), 3.98\left(\mathrm{~m}, 4 \mathrm{H}, \mathrm{C}_{5} \mathrm{H}_{4}\right), 3.92\left(\mathrm{t}, J=1,7 \mathrm{~Hz}, 2 \mathrm{H}, \mathrm{C}_{5} \mathrm{H}_{4}\right), 2.70(\mathrm{~m}$, $\left.2 \mathrm{H}, \mathrm{CH}_{2}\right), 2.34\left(\mathrm{~m}, 2 \mathrm{H}, \mathrm{CH}_{2}\right) .{ }^{13} \mathrm{C} \mathrm{NMR}\left(75.48 \mathrm{MHz}\right.$, acetone- $\left.d_{6}\right): 157.0(\mathrm{C}), 156.4(\mathrm{C})$, $141.5(\mathrm{C}), 136.0(\mathrm{C}), 135.9(\mathrm{C}), 133.4(\mathrm{C}), 132.4(2 \mathrm{CH}), 131.2(2 \mathrm{CH}), 115.7(2 \mathrm{CH}), 114.8$ $(2 \mathrm{CH}), 87.6\left(\mathrm{C} \mathrm{C}_{5} \mathrm{H}_{4}\right), 84.9\left(\mathrm{C} \mathrm{C}_{5} \mathrm{H}_{4}\right) ; 71.0\left(2 \mathrm{CH} \mathrm{C} \mathrm{C}_{5} \mathrm{H}_{4}\right), 70.8\left(2 \mathrm{CH} \mathrm{C}_{5} \mathrm{H}_{4}\right), 69.1(2 \mathrm{CH}$ $\left.\mathrm{C}_{5} \mathrm{H}_{4}\right), 68.8\left(2 \mathrm{CH} \mathrm{C} \mathrm{H}_{4}\right), 41.5\left(\mathrm{CH}_{2}\right), 29.1\left(\mathrm{CH}_{2}\right)$. Analysis: calcd for $\mathrm{C}_{26} \mathrm{H}_{22} \mathrm{FeO}_{2}$ : C 73.95\%, H 5.25\%; found: C 73.79\%, H 5.34\%. HRMS (CI $\left.-\mathrm{CH}_{4}\right)$ : calcd for $\mathrm{C}_{26} \mathrm{H}_{22} \mathrm{FeO}_{2}$ : 423.1047; found: $423.1040(\mathrm{M}+\mathrm{H})^{+}$.

\section{1,1'-\{2-[1,1-Bis (4-hydroxyphenyl) methylidene] trimethylene\} ferrocene (5).}

Compound 5 was synthesized as described for $\mathbf{4}$ but at 5\% scale, with similar workup. Yield $=0.038 \mathrm{~g}(0.090 \mathrm{mmol}, 22 \%)$ of yellow powder. ${ }^{1} \mathrm{H}$ NMR $(300.13 \mathrm{MHz}$, acetone$\left.d_{6}\right): 8.22(\mathrm{~s}, 2 \mathrm{H}, \mathrm{OH}), 7.16(\mathrm{~d}, J=8.7 \mathrm{~Hz}, 4 \mathrm{H}, \mathrm{Ar}): 6.80(\mathrm{~d}, J=8.7 \mathrm{~Hz}, 4 \mathrm{H}, \mathrm{Ar}), 4.11$ (t, $\left.J=1.9 \mathrm{~Hz}, 4 \mathrm{H} \mathrm{C}_{5} \mathrm{H}_{4}\right), 3.99\left(\mathrm{t}, J=1.9 \mathrm{~Hz}, 4 \mathrm{H}, \mathrm{C}_{5} \mathrm{H}_{4}\right), 2.81\left(\mathrm{~s}, 4 \mathrm{H}, \mathrm{CH}_{2}\right) .{ }^{13} \mathrm{C} \mathrm{NMR}(75.48$ MHz, acetone- $\left.d_{6}\right)$ : $156.7(\mathrm{C}), 141.7(\mathrm{C}), 138.6(\mathrm{C}), 135.8(\mathrm{C}), 131.0(2 \times 2 \mathrm{CH}), 115.7$ (2 x2 $\mathrm{CH}), 83.5\left(2 \mathrm{C} \mathrm{C}_{5} \mathrm{H}_{4}\right), 70.3\left(2 \times 2 \mathrm{CH} \mathrm{C}_{5} \mathrm{H}_{4}\right), 66.9\left(2 \times 2 \mathrm{CH} \mathrm{C}_{5} \mathrm{H}_{4}\right), 28,3\left(2 \mathrm{CH}_{2}\right)$. IR $(\mathrm{KBr}$, $\left.\mathrm{cm}^{-1}\right)$ : 1609, 1508, 1430, 1220, 1197, 831. HRMS $\left(\mathrm{CI}-\mathrm{CH}_{4}\right)$ : calcd for $\mathrm{C}_{26} \mathrm{H}_{23} \mathrm{FeO}_{2}$ : $423.1047(\mathrm{M}+\mathrm{H})^{+}$; found: $423.1034(\mathrm{M}+\mathrm{H})^{+}$.

Acknowledgment. We thank A. Cordaville for technical assistance and the Agence Nationale de la Recherche for financial support (no. ANR-06-BLAN-0384-01, "FerVect"). D.P.'s postdoctoral stay was financed by the Foundation for Polish Science (FNP) within the framework of the KOLUMB Fellowship. 
Supporting Information Available: Analytical instrumentation, modified synthesis of 4, biochemical testing conditions, and CV of CD-2 and CD-4. This material is available free of charge via the Internet at http://pubs.acs.org. (or see the end of this file)

\section{References}

(1) Strohfeldt, K.; Tacke, M. Bioorganometallic fulvene-derived titanocene anticancer drugs. Chem. Soc. Rev. 2008, 37, 1174-1187.

(2) Hartinger, C. G.; Dyson, P. J. Bioorganometallic chemistry;from teaching paradigms to medicinal applications. Chem. Soc. Rev. 2008, 391-401.

(3) Metzler-Nolte, N.; Salmain, M.; Stepnicka, P. The bioorganometallic chemistry of ferrocene. Ferrocenes: Ligands, Mater. Biomol. 2008, 499-639.

(4) Vessières, A.; Top, S.; Pigeon, P.; Hillard, E. A.; Boubeker, L.; Spera, D.; Jaouen, G. Modification of the estrogenic properties of diphenols by the incorporation of ferrocene. Generation of antiproliferative effects in vitro. J. Med. Chem. 2005, 48, 3937-3940.

(5) Hillard, E. A.; Vessières, A.; Le Bideau, F.; Plażuk, D.; Spera, D.; Huché, M.; Jaouen, G. A series of unconjugated ferrocenyl phenols: prospects as anticancer agents. ChemMedChem 2006, 1, 551-559.

(6) Hillard, E. A.; Pigeon, P.; Vessières, A.; Amatore, C.; Jaouen, G. The influence of phenolic hydroxy substitution on the electron transfer and anti-cancer properties of compounds based on the 2-ferrocenyl-1-phenyl-but-1-ene motif. $J$. Chem. Soc., Dalton Trans. 2007, 5073-5081.

(7) Vessières, A.; Top, S.; Beck, W.; Hillard, E. A.; Jaouen, G. Metal complex SERMs (selective estrogen receptor modulators). The influence of different metal units on breast cancer cell antiproliferative effects. Dalton Trans. 2006, 4, 529-541.

(8) Hillard, E. A.; Vessières, A.; Top, S.; Pigeon, P.; Kowalski, K.; Huché, M.; 
Jaouen, G. Organometallic diphenols: The importance of the organometallic moiety on the expression of a cytotoxic effect on breast cancer cells. J. Organomet. Chem. 2007, 692, 1315-1326.

(9) Hillard, E. A.; Vessières, A.; Thouin, L.; Jaouen, G.; Amatore, C. Ferrocenemediated proton-coupled electron transfer in a series of ferrocifen-type breast cancer drug candidates. Angew. Chem., Int. Ed. 2006, 45, 285-290.

(10) Jaouen, G.; Top, S.; Vessières, A.; Leclercq, G.; McGlinchey, M. J. The first organometallic selective estrogen receptor modulators (SERMs) and their relevance to breast cancer. Curr. Med. Chem. 2004, 11, 2505-2517.

(11) Nguyen, A.; Vessières, A.; Hillard, E. A.; Top, S.; Pigeon, P.; Jaouen, G. Ferrocifens and ferrocifenols as new potential weapons against breast cancer. Chimia 2007, 61, 716-724.

(12) Minutolo, F.; Sala, G.; Bagnacani, A.; Bertini, S.; Carboni, I.; Placanica, G.; Prota, G.; Rapposelli, S.; Sacchi, N.; Macchia, M.; Ghidoni, R. Synthesis of a resveratrol analogue with high ceramide-mediated proapoptotic activity on human breast cancer cells. J. Med. Chem. 2005, 48, 6783-6786.

(13) Vessières, A.; Spera, D.; Top, S.; Misterkiewicz, B.; Heldt, J. M.; Hillard, E. A.; Huché, M.; Plamont, M. A.; Napolitano, E.; Fiaschi, R.; Jaouen, G. The presence of a ferrocenyl unit on an estrogenic molecule is not always sufficient to generate in vitro cytotoxicity. ChemMedChem 2006, 1, 1275-1281.

(14) Dogan, O.; Senol, V.; Zeytinci, S.; Koyuncu, H.; Bulut, A. Efficient synthesis of ferrocenylenones by Friedel-Crafts acylation with $\mathrm{EtAlCl}_{2}-\mathrm{Me}_{3} \mathrm{Al}$. J. Organomet. Chem. 2005, 690, 430-434.

(15) Turbitt, T. D.; Watts, W. E.; Bridged ferrocenes, X. I. I. The synthesis of [3] ferrocenophan-1-one from ferrocene by a novel one-step annelation reaction. $J$. Organomet. Chem. 1972, 46, 109-117.

(16) Plażuk, D.; Zakrzewski, J. Acylation of ferrocene and a 1,1'-diphosphaferrocene with acyl trifluoroacetates in the presence of trifluoromethanesulfonic (triflic) 
acid or some metal triflates. Synth. Commun. 2004, 34, 99-107.

(17) Mock, W.; Richards, J. H. The synthesis of bridged ferrocene derivatives with functional groups on the $\beta$-carbon of the bridge. J. Org. Chem. 1962, 27, 4050 4051.

(18) Buriez, O.; Heldt, J. M.; Labbé, E.; Vessières, A.; Jaouen, G.; Amatore, C. Reactivity and antiproliferative activity of ferrocenyl-tamoxifen adducts with cyclodextrins against hormone-independent breast-cancer cell lines. Chem.;Eur. J. 2008, 14, 8195-8203.

(19) Top, S.; Dauer, B.; Vaissermann, J.; Jaouen, G. Facile route to ferrocifen, 1-[4(2-dimethylaminoethoxy)]-1(phenyl-2-ferrocenyl-but-1-ene), first organometallic analogue of tamoxifen, by the McMurry reaction. J. Organomet. Chem. 1997, $541,355-361$.

(20) Hapiot, F.; Tilloy, S.; Monflier, E. Cyclodextrins as supramolecular hosts for organometallic complexes. Chem. Rev. 2006, 106, 767-781.

(21) Menger, F. M.; Sherrod, S. J. Docking calculations on ferrocene complexation with cyclodextrins. J. Am. Chem. Soc. 1988, 110, 8606-8611.

(22) Hitasome, M.; Watanabe, J.; Yamakawa, K. Selective oxidation of the $\alpha$-methylene of the bridge in ferrocenophanes with silver oxide or silver perchlorate/sodium methoxide. Bull. Chem. Soc. Jpn. 1994, 67, 280-283.

(23) Signorelli, P.; Ghidoni, R. Resveratrol as an anticancer nutrient: molecular basis, open questions and promises. J. Nutr. Biochem. 2005, 16, 449-466.

(24) Allard, E.; Passirani, C.; Garcion, E.; Pigeon, P.; Vessières, A.; Jaouen, G.; Benoit, J. P. Lipid nanocapsules loaded with an organometallic tamoxifen derivative as a novel drug-carrier system for experimental malignant gliomas. $J$. Controlled Release 2008, 130, 146-153.

(25) Michard, Q.; Jaouen, G.; Vessières, A.; Bernard, B. A. Evaluation of cytotoxic properties of organometallic ferrocifens on melanocytes, primary and metastatic melanoma cell lines. J. Inorg. Biochem. 2008, 102, 1980-1985. 


\section{Supporting Information}

\section{Analytical Instrumentation}

Infrared spectra were obtained on an IRFT BOMEM Michelson-100 spectrometer equipped with a DTGS detector as a $\mathrm{KBr}$ plate. ${ }^{1} \mathrm{H}$ and ${ }^{13} \mathrm{C}$ NMR spectra were recorded on a $300 \mathrm{MHz}$ Bruker spectrometer. Mass spectrometry was performed with a Nermag R 10-10C spectrometer. Melting points were measured with a Kofler device. Elemental analyses were performed by the microanalysis service of CNRS at Gif sur Yvette. Electrochemical experiments were performed Cyclic voltammograms were obtained utilizing a Princeton Applied Research potentiostat. Analyte solutions were $1 \mathrm{mM}$ in DMF with $0.1 \mathrm{M} \mathrm{Bu}_{4} \mathrm{NBF}_{4}$ supporting electrolyte. Cyclic voltammetry experiments were performed at room temperature under an argon atmosphere in a three-electrode cell. The reference electrode was an SCE (Tacussel), which was separated from the solution by a bridge compartment filled with the same solvent/supporting electrolyte solution as used in the cell. The counter electrode was a platinum mesh (Goodfellow). The platinum working electrode was home-made $(0.5 \mathrm{~mm}$ diameter; Goodfellow).

\section{Synthesis of Intermediates}

Ethyl ferrocenoylacetate, $\mathbf{6}$ was prepared by slightly modified procedure for acylation of ferrocene with acyl trifluoroacetate. ${ }^{1}$ To a stirred solution of $13.2 \mathrm{~g}$ of ethyl mono-malonate and $21 \mathrm{~g}(14 \mathrm{ml})$ of trifluoroacetic anhydride in $100 \mathrm{ml}$ of dichloromethane was added $18.6 \mathrm{~g}$ of ferrocene. After $5 \mathrm{~min}$ a solution of $30 \mathrm{ml}$ of methanesulfonic acid in $50 \mathrm{ml}$ of dichloromethane was added. The resulting violet mixture was stirred at room temperature. After $4 \mathrm{~h}$ the reaction mixture was poured onto ice $(300 \mathrm{~g})$ and the resulting solution was neutralized by addition of solid $\mathrm{NaHCO}_{3}$. Products were extracted with DCM. Chromatography on silica gel (DCM - ethyl acetate $95-5$ ) gave 18 g of pure product. ${ }^{1} \mathrm{H},{ }^{13} \mathrm{C}$ NMR confirmed the structure as reported in the literature. ${ }^{2}$

Ethyl 3-ferrocenylpropionate, 7 was prepared as previously described ${ }^{3}$ for the synthesis of ferrocenylbutyric acid. To a mixture of $70 \mathrm{~g}$ of zinc dust and $10 \mathrm{~g}$ of $\mathrm{Hg}(\mathrm{OAc})_{2}$ in $150 \mathrm{ml}$ of water, $5 \mathrm{ml}$ of $37 \% \mathrm{HCl}$ was added and the resulting mixture was stirred for $10 \mathrm{~min}$. The aqueous solution was decanted and the $\mathrm{Zn} / \mathrm{Hg}$ was washed 4 times with $200 \mathrm{ml}$ portions of water. The mixture of $\mathrm{Zn} / \mathrm{Hg}$, the solution of $10 \mathrm{~g}$ of $\mathrm{FcCOCH}_{2} \mathrm{COOEt}$ in $160 \mathrm{ml}$ of toluene, $40 \mathrm{ml}$ of water and $60 \mathrm{ml}$ of $37 \% \mathrm{HCl}$ was stirred and refluxed for $4 \mathrm{~h}$ (only one product on TLC - hexane). After cooling to room temperature the organic solution was separated and the inorganic residue extracted with toluene. The toluene solution was washed with sat. aq. $\mathrm{NaHCO}_{3}$ and dried with $\mathrm{MgSO}_{4}$. Evaporation of the solvents gave the product in quantitative yield. The ${ }^{1} \mathrm{H}$ and ${ }^{13} \mathrm{C}$ NMR spectra confirmed the structure as reported in the literature. ${ }^{4}$

Ferrocenylpropionic acid, 8. A mixture of $9 \mathrm{~g}$ of 7, $25 \mathrm{ml}$ of EtOH, and $100 \mathrm{ml}$ of $20 \%$ aq. solution of $\mathrm{NaOH}$ was refluxed. After $3 \mathrm{~h}$ the resulted solution was diluted with $200 \mathrm{ml}$ of water and extracted with several portion of diethyl ether and the aqueous solution was filtered and acidified with conc. $\mathrm{HCl}$ to $\mathrm{pH} 1.8$ was extracted twice with $100 \mathrm{ml}$ portions of DCM, organic solution was washed twice with $200 \mathrm{ml}$ portions of water and dried. Evaporation of solvent gave $5.3 \mathrm{~g}$ of pure 8. Crystallization from DCM $-n$-pentane gave product as a yellow powder. ${ }^{1} \mathrm{H},{ }^{13} \mathrm{C}$ NMR confirmed the structure as reported in the literature. ${ }^{5}$ 


\section{Biochemical studies}

Materials. Stock solutions $\left(1 \times 10^{-3} \mathrm{M}\right)$ of the compounds to be tested were prepared in DMSO and were kept at $4{ }^{\circ} \mathrm{C}$ in the dark; under these conditions they are stable at least two months. Serial dilutions in DMSO were prepared just prior to use. Dulbecco's modified eagle medium (DMEM) with phenol red/Glutamax I, Dulbecco's modified eagle medium (DMEM) without phenol red, Glutamax I and fetal bovine serum (FBS) were purchased from Invitrogen; estradiol from Sigma. PC-3 and MDA-MB-231 cells were from American Type Culture Collection (ATCC, LGC Promochem). Sheep uteri weighing approximately $7 \mathrm{~g}$ were obtained from the slaughterhouse at Mantes-la-Jolie, France. They were immediately frozen and kept in liquid nitrogen prior to use.

Determination of the Relative Binding Affinity (RBA) of the compounds for ER $\alpha$ and ER $\beta$. RBA values were measured on ER $\alpha$ from lamb uterine cytosol and on ER $\beta$ Panvera purchased from Invitrogen ( France ). Sheep uterine cytosol prepared in buffer A (0.05 M Tris-HCL, $0.25 \mathrm{M}$ sucrose, $0.1 \%$ Bmercaptoethanol, $\mathrm{pH} 7.4$ at $25^{\circ} \mathrm{C}$ ) was used as a source of $\mathrm{ER} \alpha$. For ER $\beta, 10 \mu \mathrm{l}$ of the solution containing $3500 \mathrm{pmol} / \mathrm{ml}$ were added to $16 \mathrm{ml}$ of buffer B (10\% glycerol, $50 \mathrm{mM}$ Bis-Tris-Propane $\mathrm{pH}=9,400 \mathrm{mM} \mathrm{KCl}, 2 \mathrm{mM}$ DTT, $1 \mathrm{mM}$ EDTA, $0.1 \% \mathrm{BSA})$ in a silanized flask. Aliquots $(200 \mu \mathrm{l})$ of ER $\alpha$ in glass tubes or ER $\beta$ in polypropylene tubes were incubated for $3 \mathrm{~h}$ at $0{ }^{\circ} \mathrm{C}$ with $[6,7-3 \mathrm{H}]$-estradiol $\left(2 \times 10^{-9} \mathrm{M}\right.$, specific activity $1.62 \mathrm{TBq} / \mathrm{mmol}$, NEN Life Science, Boston MA) in the presence of nine concentrations of the hormones to be tested. At the end of the incubation period, the free and bound fractions of the tracer were separated by protamine sulfate precipitation. The percentage reduction in binding of $[3 \mathrm{H}]$-estradiol $(\mathrm{Y})$ was calculated using the logit transformation of $\mathrm{Y}$ (logitY: $\ln [\mathrm{y} / 1-\mathrm{Y}]$ versus the $\log$ of the mass of the competing steroid. The concentration of unlabeled steroid required to displace $50 \%$ of the bound $[3 \mathrm{H}]$-estradiol was calculated for each steroid tested, and the results expressed as RBA. The RBA value of estradiol is by definition equal to $100 \%$.

Culture conditions. Cells were maintained in a monolayer culture in DMEM with phenol red/Glutamax I supplemented with $9 \%$ fetal bovine serum at $37{ }^{\circ} \mathrm{C}$ in a $5 \% \mathrm{CO}_{2} /$ airhumidified incubator. For proliferation assays, PC-3 and MDAMB-231 cells were plated in 1 $\mathrm{mL}$ of DMEM without phenol red, supplemented with $9 \%$ decomplemented and hormonedepleted fetal bovine serum, $0.9 \%$ kanamycin, $0.9 \%$ Glutamax I and incubated. The following day (D0), $1 \mathrm{~mL}$ of the same medium containing the compounds to be tested was added to the plates. After 3 days (D3) the incubation medium was removed and $2 \mathrm{~mL}$ of the fresh medium containing the compounds was added. After 5 days the total protein content of the plate was analyzed as follows: cell monolayers were fixed for $1 \mathrm{~h}$ at room temperature with methylene blue $\left(1 \mathrm{mg} \mathrm{mL}^{-1}\right.$ in 50:50 water/MeOH mixture), then washed with water. After addition of $\mathrm{HCl}(0.1 \mathrm{M}, 2 \mathrm{~mL})$, the plate was incubated for $1 \mathrm{~h}$ at $37^{\circ} \mathrm{C}$ and then the absorbance of each well (6 wells for each concentration) was measured at $655 \mathrm{~nm}$ with a Biorad spectrophotometer. The results are expressed as the percentage of proteins versus the control. 


\section{Cyclic voltammogram of CD-4}

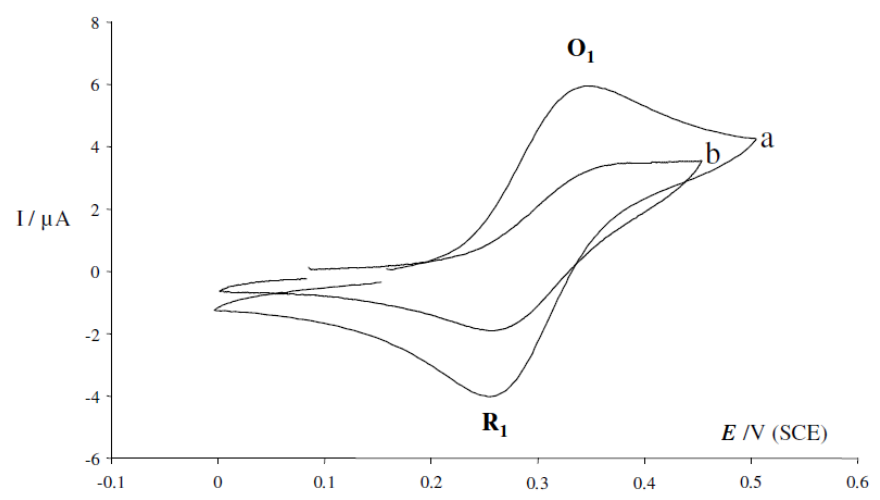

Figure S1. Cyclic voltammogram of a) 4 and b) $2(1 \mathrm{mM})$ in $\mathrm{H}_{2} \mathrm{O}+\mathrm{Na}_{2} \mathrm{SO}_{4}(0.1 \mathrm{M})$ recorded at a glassy carbon electrode ( $3 \mathrm{~mm}$ diameter) at $50 \mathrm{mV} \mathrm{s}^{-1}$, in the presence of 20 eq. Me- $\beta$ CD. $\mathrm{O}_{1}$ and $\mathrm{R}_{1}$ refer to the oxidation and reduction waves, respectively.

${ }^{1}$ D. Plazuk, J. Zakrzewski Synthetic Communications 2004, 34(1), 99-107.

${ }^{2}$ B. Floris, P. Galloni, R. Seraglia, P. Tagliatesta Journal of Organometallic Chemistry 2003 679, 202-207.

${ }^{3}$ K. L. Rinehart Jr .,R. J. Curby Jr., D. H. Gustafson, K. G. Harrison, R. E. Bozak, D. E. Bublitz J. Amer. Chem. Soc. 1962, 84, 3263-3269.

4 C. M. Zakaria, C. A. Morrison, D. McAndrew, W. Bell, C. Glidewell Journal of Organometallic Chemistry 1995, 485, 201-207.

${ }^{5}$ A. Anne, B. Blanc, J. Moiroux Bioconjugate Chem. 2001, 12, 396-405. 